\title{
Immune Responses in Malaria
}

\author{
Carole A. Long ${ }^{1}$ and Fidel Zavala ${ }^{2}$ \\ ${ }^{1}$ Laboratory of Malaria and Vector Research, National Institute of Allergy and Infectious Diseases, \\ National Institute of Health, Rockville, Maryland 20852 \\ ${ }^{2}$ Departmentof Molecular Microbiology and Immunology, Bloomberg School of Public Health, \\ Johns Hopkins University, Baltimore, Maryland 21205 \\ Correspondence: clong@niaid.nih.gov; fzavala1@jhu.edu
}

Evidence accumulated through the years clearly indicates that antiparasite immune responses can efficiently control malaria parasite infection at all development stages, and under certain circumstances they can prevent parasite infection. Translating these findings into vaccines or immunotherapeutic interventions has been difficult in part because of the extraordinary biological complexity of this parasite, which has several developmental stages expressing unique sets of stage-specific genes and multiple antigens, most of which are antigenically diverse. Nevertheless, in the last 30 years major advances have resulted in characterization of a number of vaccine candidates, exploration of the repertoire of host immune responses to the various parasite stages, and also identification of significant hurdles that need to be overcome. Most important, these advances strengthened the concept that the induction of host immune responses that target all developmental stages of Plasmodium can efficiently control or abrogate Plasmodium infections and strongly support the notion that an effective vaccine can be developed. This vaccine would be a critical component for programs aimed at controlling or eradicating malaria.

$\mathrm{n}$ this review, we address immune responses to the various stages of parasite developmentpreerythrocytic, asexual stages in red cells, and sexual and mosquito stages. Our expanding understanding of these responses and their targets provides a foundation for the development of vaccines directed at the three major developmental stages of malaria parasites.

\section{IMMUNE RESPONSES TO PREERYTHROCYTIC (PE) ANTIGENS}

\section{Antibody Responses to PE Antigens}

Early studies in rodent malaria showed that immunization with attenuated Plasmodium ber- ghei sporozoites induced antibodies that recognized the sporozoite surface and neutralized their infectivity (Nussenzweig et al. 1967). Subsequent studies in which humans were immunized with attenuated Plasmodium falciparum sporozoites confirmed the protective efficacy of the sporozoite-induced immune responses (Rieckmann et al. 1979). Humans naturally exposed to parasite infection in endemic areas also develop antisporozoite responses, as indicated by studies in malaria-endemic areas of Africa and Asia, which reported that antisporozoite antibodies are most frequently detected in individuals older than 50 years and in only a minority of children (Nardin et al. 1979; Tapchaisri

Editors: Dyann F. Wirth and Pedro L. Alonso

Additional Perspectives on Malaria: Biology in the Era of Eradication available at www.perspectivesinmedicine.org

Copyright (C) 2017 Cold Spring Harbor Laboratory Press; all rights reserved; doi: 10.1101/cshperspect.a025577

Cite this article as Cold Spring Harb Perspect Med 2017;7:a025577 
et al. 1983; Druilhe et al. 1986). In vitro assays with sera from endemic areas showed that sporozoite-reactive sera inhibit sporozoite invasion of hepatocytes in vitro (Hollingdale et al. 1984; Hoffman et al. 1986; Mellouk et al. 1986; Hollingdale et al. 1989).

The antibodies that bind to sporozoites recognize different antigens. Among these, the circumsporozoite protein (CSP) was the first antigen identified in rodent and human malaria sporozoites (Nussenzweig and Nussenzweig 1989). A CSP-based vaccine (RTS,S) has undergone a phase III vaccine trial, and is discussed in detail in Healer et al. (2016). Anti-CSP antibodies bind the entire surface of sporozoites and induce the shedding of the CSP (Stewart et al. 1986). Most of them recognize the repeat domain of this protein, which is conserved in all strains of $P$. falciparum (Zavala et al. 1985a). Most importantly, they inhibit sporozoite infectivity in vivo and in vitro (Zavala et al. 1985b; Persson et al. 2002). Longitudinal studies, focused on antibodies specific for the CSP repeats showed an age-dependent distribution of antibodies as had been observed using an immunofluorescence antibody (IFA) assay (Zavala et al. 1985b; Del Giudice et al. 1987, 1990).

Studies in endemic areas revealed that the presence of anti-CSP antibodies correlated with transmission exposure and increased with age (Campbell et al. 1987; Esposito et al. 1988; Marsh et al. 1988). Studies on the carboxyand amino-terminal regions flanking the repeat domain indicate that they contain important functional domains that enable sporozoite infectivity (Coppi et al. 2011). Sera from endemic areas contain antibodies against nonrepeat regions of the CSP, and the presence of $P$. falciparum amino-terminal-specific antibodies has been associated with the development of clinical immunity (Bongfen et al. 2009). Recently, it was shown that antibodies against this aminoterminal region strongly inhibit sporozoite infectivity in vivo (Espinosa et al. 2015).

Thrombospondin-related adhesive protein (TRAP) (Robson et al. 1988) is a parasite antigen also considered as a vaccine candidate. This is a transmembrane protein containing adhesive domains that enable the motility of sporozoites in mosquitoes and vertebrate hosts, mediating their migration from skin to the liver. Early studies showed that sera from individuals immunized with $P$. falciparum sporozoites had antibodies against TRAP and these antibodies inhibited sporozoite infection of hepatocytes in vitro (Rogers et al. 1992). In Mali, the presence of antibodies against TRAP was associated with lower parasitemia, protection against infection (Scarselli et al. 1993; John et al. 2003), and protection against cerebral malaria (Dolo et al. 1999). Antibodies against TRAP are short lived in children, waning significantly during the dry season (John et al. 2003), as also observed with anti-CSP antibodies (Marsh et al. 1988).

LSA1 is a $197-\mathrm{Kd}$ molecule consisting of a large number of repeated sequences, expressed exclusively in $P$. falciparum during early liver stages and no ortholog exists in rodent parasites (Guerin-Marchand et al. 1987; Zhu and Hollingdale 1991). This antigen is widely recognized by sera from individuals living in endemic areas (Fidock et al. 1994; Kurtis et al. 2001). Studies using sera from children in Gabon reported an association between anti-LSA1 titers and partial resistance to infection (Domarle et al. 1999). Another antigen, CelTOS (cell-traversal protein for ookinetes and sporozoites) (Kariu et al. 2006) is a conserved protein present in two different motile stages and appears to elicit cross-species protection (BergmannLeitner et al. 2010). Limited epidemiologic information on CelTOS indicates that individuals living in endemic areas develop cellular and humoral responses against this antigen (Anum et al. 2015).

Studies in Kenya that evaluated antibody responses to CSP, LSA-1, and TRAP, indicated that antibody levels against these three antigens, instead of a single antigen, displayed a stronger correlation with lower incidence and reduced risk of clinical malaria, as well as with diminished severity of disease (John et al. 2005, 2008). Recent studies using high-throughput assays to screen hundreds of Plasmodium antigens revealed that, compared to blood-stage reactivity, there was an infrequent reactivity to preerythrocytic antigens (Doolan et al. 2008; Crompton et al. 2010). These studies associated pro- 
tection with the breadth of antigens recognized instead of responses to single antigens.

Overall, studies with sera from individuals living in endemic areas and volunteers immunized with irradiated sporozoites indicate that the development of antibodies against sporozoite antigens is clearly age and dose dependent, and their magnitude is limited. There is a consensus that antibodies induced by natural exposure may in some areas correlate with partial protection but they do not confer sterile immunity.

\section{T-Cell Responses to Preerythrocytic (PE) Antigens}

The notion that $\mathrm{T}$ cells can be an effective antiparasite immune mechanism derives from studies in rodent models showing that $\mathrm{CD}^{+}$and $\mathrm{CD} 4^{+} \mathrm{T}$ cells inhibit the development of malaria liver stages (Tsuji and Zavala 2003). Studies in endemic areas indicate that naturally exposed individuals are able to mount specific $\mathrm{CD} 8^{+}$ T-cell responses to CSP and TRAP, but these responses are low in magnitude and detectable only in a minority of individuals (Doolan et al. 1993; Flanagan et al. 2003). Studies in some endemic areas failed to detect $\mathrm{CD} 8^{+} \mathrm{T}$-cell responses against any of the overlapping peptides representing the entire CSP sequence, including most of the variant isolates (Doolan et al. 1991). A study in Kenya suggested a degree of protection against anemia among individuals that produced interferon $\gamma(\mathrm{IFN}-\boldsymbol{\gamma})$ in response to TRAP peptides (Ong'echa et al. 2003). Human vaccine trials using recombinant viruses as immunogens have shown the induction of $\mathrm{CD}^{+}$ T-cell responses against these antigens and an association with partial protection (Ewer et al. 2013).

$\mathrm{CD}^{+} \mathrm{T}$ cells against CSP are also found in individuals living in endemic areas. Early studies showed that several epitopes are recognized in both the CSP of Plasmodium vivax and $P$. falciparum, and these responses appear to be more frequent against polymorphic epitopes (Good et al. 1988; Zevering et al. 1994) The presence of CSP-specific $\mathrm{CD} 4^{+} \mathrm{T}$ cells in individuals living in endemic areas did not show correlation with clinical immunity (de Groot et al. 1989; Riley et al. 1990; Esposito et al. 1992). T-cell responses against other antigens such as HEP17 (Doolan et al. 1996) and STARP (Fidock et al. 1994) have also been identified; however, these antigens are expressed in liver and asexual stages and therefore the target of their potential protective effect remains to be defined.

The difficulties in detecting robust T-cell responses against $\mathrm{PE}$ antigens in individuals living in endemic areas contrasts with the relative ease at which these responses are detected in volunteers immunized with attenuated sporozoites (Seder et al. 2013) or subunit vaccines (Ewer et al. 2013). This indicates that natural exposure to parasite antigens may not be sufficient to induce robust T-cell responses. Taken together, naturally acquired antibody and T-cell responses against $\mathrm{PE}$ antigens are of low magnitude and infrequent, particularly in children. Although some studies indicate an association of naturally induced immune responses with clinical immunity, these responses may never confer sterile protection. This is likely because of low antigen inoculum received by individuals as mosquitoes inject only a few sporozoites $(10-100)$ and this may not be sufficient to induce strong immune responses. Indeed, anti-PE responses induced in humans after immunization with attenuated sporozoites can confer a high degree of sterile protection, but this requires exposure to 1000 infective bites (Herrington et al. 1991) or the intravenous injection of several hundred thousand sporozoites (Seder et al. 2013). Decades of studies on the CSP protein laid the groundwork for the development and testing of the RTS,S vaccine, which is based on this protein using a platform of a hepatitis B particle (discussed in Healer et al. 2016). However, this vaccine is only partially effective and its longevity is limited. The development of a more efficient PE vaccine that could effectively contribute to eradication efforts will require a better understanding of the immune mechanisms operating in sporozoite-induced immunity, the identification of additional target antigens, and the design of a new generation of vaccines capable of inducing not only high 
C.A. Long and F. Zavala

antibody titers but also strong cell-mediated immune protection.

\section{IMMUNE RESPONSES TO ASEXUAL ERYTHROCYTIC STAGES}

The asexual stages of malaria parasites have been intensively investigated because they are most accessible to investigators in the blood of an infected person and because they are responsible for the pathology associated with this disease. It is known that those living in malariaendemic areas progressively develop partial resistance to infection with $P$. falciparum, although this takes many years to attain (reviewed in Beeson et al. 2008; Langhorne et al. 2008; Crompton et al. 2014). The classic depiction of the natural history of immunity to malaria as a function of age was provided by long-term studies in Kenya (Marsh and Kinyanjui 2006). As illustrated in Marsh and Kinyanjui (2006), these studies revealed that young children are likely to have the highest parasitemias and also are more likely to develop severe malaria pathology (Milner 2016). As children age, they are still susceptible to infection accompanied by clinical symptoms but are less likely to develop severe disease. This pattern continues into adolescence and adulthood with even fewer clinical symptoms but still the periodic presence of parasites. Studies on the acquisition of immunity to $P$. vivax indicate that resistance may be acquired more rapidly than with $P$. falciparum (reviewed in Mueller 2013).

Perhaps the most important finding in our understanding of this naturally acquired immunity to $P$. falciparum malaria was published in 1961 (Cohen et al. 1961). That study established that pooled IgG antibodies from African adults living in a malaria-endemic area could dramatically drive down parasitemias when passively transferred to children with malaria. It was later confirmed and extended using IgGs from Africans transferred to Asians failing chemotherapy for malaria (Sabchareon et al. 1991). Its functionality, despite the geographic distance, provided evidence that the protective antibodies either recognized conserved determinants or a very broad range of allelic types. These experi- ments have provided the experimental foundation for efforts to develop a malaria vaccine, historically with the main goal of protecting children against severe disease and death. Despite all this time we are not certain of the antigenic targets of those protective antibodies nor are we certain of the effector mechanisms involved in the reduction of parasite burden. Further, we do not know the contribution of $\mathrm{T}$ cells (beyond helper function) or other cells of the immune system to these responses. The large number of parasite-encoded proteins (approximately 5400 genes) and the allelic diversity of many of those proteins have complicated the identification of targets of protective immune responses as well as efforts to develop vaccines that elicit broadly reactive protective responses. Nevertheless, the fact that people living in endemic areas become at least partially immune to malaria provides evidence that a vaccine against this disease should be possible. Overall, progress has been slow and results of phase II clinical trials testing several blood-stage vaccine candidates have been disappointing (Healer et al. 2016). Thus, there is significant impetus for identification of new potential vaccine candidates and combinations of candidates from blood stages, expanded efforts to understand the important cells and effector mechanisms to be targeted, and exploration of immunization strategies that would elicit these responses.

\section{Effector Mechanisms and Assays}

Selection of malaria vaccine candidates and their rapid evaluation has been hampered by numerous problems, including difficulties encountered in expressing novel malaria proteins in recombinant protein expression systems in a correct configuration and the lack of assays and markers, which predict protection in vivo. Many investigators have shown that those infected with malaria parasites produce an array of antibodies against many different asexualstage proteins and these have usually been examined one at a time. More recent studies have extended these results using microarrays with Escherichia coli produced proteins (Gray et al. 2007; Doolan et al. 2008; Crompton et al. 2010). 
It has been difficult to correlate responses to individual parasite proteins with protection, although it has been proposed that cytophilic IgG1 and IgG3 isotypes are more correlated with protective responses (Bouharoun-Tayoun and Druilhe 1992).

Assessing these antibodies has ranged from direct enzyme-linked immunosorbent assay (ELISA) measurements to evaluation of functional activity using assays such as in vitro parasite growth inhibition, opsonization with antibodies and leukocytes, complement fixation, measuring antibodies to proteins on the erythrocyte surface by flow cytometry or agglutination tests, and antibody-dependent cellular cytotoxicity assays. However, it has been difficult to correlate any single assay with clinical protection, so the relative contribution of these antibody effector functions in vivo is not established.

\section{Merozoite Proteins}

Merozoite proteins have been the focus of most studies of immune responses to the asexual stages of infection and work in Cowman et al. (2012) discusses the architecture of a merozoite as well as its organelles and some of the proteins involved in invasion. One of the first merozoite proteins to be investigated was the merozoite surface protein 1 (MSP1), one of a number of MSP molecules, which provide a surface coating for merozoites and likely contribute to the invasion process. Monoclonal antibodies to the carboxyl terminus of this large protein were able to protect mice passively against lethal challenge with the rodent parasite Plasmodium yoelii (Majarian et al. 1984; Burns et al. 1989), and subsequent studies established that both mice and Aotus monkeys could be immunized against a lethal parasite challenge using either the P. yoelii or P. falciparum MSP1 carboxyl terminus (Daly and Long 1993; Stowers et al. 2001). Later efforts to move this candidate into human clinical trials in Africa proved disappointing (Ogutu et al. 2009). Humans living in malaria-endemic areas do develop antibodies to MSP1, and in some cases these responses have been associated with protection. Apical membrane antigen 1 (AMA1) (Deans et al. 1982; reviewed in Remarque et al. 2008) is a micronemal protein, which is translocated to the merozoite surface during invasion and, in conjunction with RON2, contributes to the moving junction on the red cell during invasion (Lamarque et al. 2011); it is also present in sporozoites. Its critical central role during erythrocyte invasion has made it a target for both vaccines and drugs, and immunization-challenge studies with PfAMA1 in Aotus monkeys showed protective responses (Stowers et al. 2002). Further, antibodies to AMA1 from a variety of animal species strongly inhibit red cell invasion in vitro, and antibodies to it are commonly found in those living in endemic areas, including young children. Nevertheless, this has presented significant problems for investigators because of the allelic diversity found in different strains of P. falciparum (Thomas et al. 1990), and success in human clinical trials has been limited (Sagara et al. 2009; Thera et al. 2011). However, several groups have shown in preclinical studies that immunization with a mixture of four to five alleles elicits antibodies with greater cross-strain specificity (Dutta et al. 2013; Miura et al. 2013b; Terheggen et al. 2014), and immunization with AMA1 combined with RON2 may elicit more effective responses (Srinivasan et al. 2014).

Other merozoite proteins involved in erythrocyte binding have been examined as possible targets of protective host immune responses. Most can be categorized as erythrocyte bindinglike (EBL) or reticulocyte binding-like (RBL or Rh) (reviewed in Tham et al. 2012). These are located in the apical organelles and some have been shown to be targets of invasion-inhibiting antibodies. However, the existence of multiple parasite-encoded ligands has allowed these organisms to use redundant invasion pathways and potentially escape host immune responses (reviewed by Wright and Rayner 2014).

One of these proteins, PfRh5 (reticulocytebinding protein homolog), has been identified as a critical merozoite component because of its binding to basigin on the red cell membrane (Crosnier et al. 2011). PfRh5 also interacts with two other parasite molecules, PfRipr (Chen et al. 2011) and CyRPA (Reddy et al. 2015). 
Although people living in a malaria-endemic area generally develop low levels of antibody to PfRh5 (Douglas et al. 2011; Tran et al. 2014), animals immunized with this antigen can produce antibodies with significant growth inhibition activity (Douglas et al. 2014) and, in the case of nonhuman primates, show protective immune responses even against heterologous parasites (Douglas et al. 2015).

\section{Parasite Proteins on the Infected Red Cell Surface}

There are several multigene families encoding important proteins exported to the infected red cell membrane. Perhaps the most important are the complex VAR proteins encoded by the large, polymorphic PfEMP1 (erythrocyte membrane protein) gene family with approximately 60 members with different var repertoires in different parasite strains (reviewed in Chan et al. 2014; Hviid and Jensen 2015). These large proteins have multiple variant domains, which bind ligands such as CD36 and ICAM-1 on host tissues and contribute to sequestration of $P$. falciparum parasites on the vascular endothelium (see Smith 2014 for review of adhesion domains). This has resulted in some variants being associated with specific disease pathogenesis such as cerebral malaria (Milner 2016). PfEMP1 proteins are displayed on the surface of the infected red cell for many hours and would be excellent targets for host immune responses, but their complexity, antigenic heterogeneity, and ability to switch from one PfEMP1 protein to another are daunting for vaccinology. However, it is clear that those living in malaria-endemic areas develop antibodies to the surfaces of infected red cells and these responses have been implicated in naturally acquired immunity, perhaps by sequential acquisition of antibodies caused by infection with various parasite strains (Bull et al. 1998; Mackintosh et al. 2008; Chan et al. 2012).

The most defined member of this family is VAR2CSA, a member of the PfEMP1 family, which has been implicated in pregnancy-associated malaria because of its binding to chondroitin-sulfate A (CSA) found in the placenta (Fried and Duffy 2016). Multiparous women develop antibodies to VAR2CSA and these antibodies appear to contribute to their resistance to placental malaria after the first pregnancy (reviewed in Ataide et al. 2014). Localization of important target epitopes within this large molecule, producing correct conformation of specific domains, and some allelic variation have all complicated studies with this molecule.

Two other polymorphic gene families are the rifins (repetitive interspersed family) and the stevors (subtelomeric variant open reading frame), which encode the RIFINS and STEVOR protein families. Much less is known about these proteins and immune responses to them, although recent evidence has indicated that both the RIFINS (Goel et al. 2015) and the STEVORS (Niang et al. 2014) can promote rosetting of red blood cells; this is an aggregation of infected and uninfected red cells, which in some studies has been suggested to contribute to malaria pathogenesis (Carlson et al. 1990).

\section{Protective Immune Responses}

Given the wide array of humoral immune responses to various antigens associated with asexual stages, a meta-analysis of the literature was conducted to try to associate antibodies to specific merozoite proteins with incidence of $P$. falciparum malaria (Fowkes et al. 2010). Some limited associations were noted with proteins such as MSP3 and MSP1-19, but it is unclear whether these are cause-and-effect relationships. Overall, evidence has accumulated based on results in model systems that high levels of antibodies to merozoite antigens are likely to be required to achieve protection in humans. This is thought to be because of the short window available to attack extracellular merozoites before they enter a new red cell. Further, the major clinical trials of blood-stage vaccines have been performed with single antigens and it is likely that combinations of antigens will be required. In this context, protection from clinical malaria has been reported to be associated with both the breadth and magnitude of the antibody responses to merozoite antigens (Osier et al. 2008).

Other potential targets of naturally acquired immunity are the variant surface antigens 
present on the membranes of infected red cells. It has been suggested that this immunity depends on acquisition of antibodies to these antigens and that the complexity and variability of protein families such as PfEMP1 requires the progressive accumulation of antibodies to different variants over time (reviewed in Chan et al. 2014; Smith 2014; Hviid and Jensen 2015). It may be that robust antibody responses to both merozoite and cell surface antigens are required to attain naturally acquired clinical immunity although there is limited data on this possibility and replicating it in vaccines remains a challenge.

In the context of elimination/eradication, the question has been raised as to the rationale for asexual-stage vaccines, especially given that they may be only partially effective. However, there are still large numbers of children susceptible to serious disease caused by malaria. Moreover, as malaria continues to decline, much larger numbers of adolescents and adults will not have the benefit of naturally acquired immunity and will be susceptible to serious illness if malaria resurges. Having a vaccine that can provide protection to these people will continue to be of relevance in malaria immunity.

\section{Impact of Malaria Infection on the Immune System}

Infection by asexual stages of plasmodia triggers an array of signals and responses in both the innate and adaptive host immune systems. Whether these responses contribute to protection or pathology or both has been difficult to evaluate, particularly in human studies. Although the evidence for a protective role of $B$ cells and antibodies has been noted, the direct contribution of $\mathrm{CD} 4^{+} \mathrm{T}$ cells in protection against blood stages beyond a helper function for $\mathrm{CD}^{+}{ }^{+} \mathrm{T}$ cells has mainly derived from rodent models of malaria. For example, it has been shown that $\mathrm{CD}^{+} \mathrm{T}$ cells can dramatically reduce infection with Plasmodium chabaudi in the absence of B cells (Grun and Weidanz 1981). Many other cell types have been implicated in these complex responses as well.

Innate immune cells can be activated by various pathogen-associated molecular patterns
(PAMPs); some of the PAMPs implicated include hemozoin, parasite DNA, and the glycosylphosphatidylinositol anchors of malaria proteins (reviewed in Gazzinelli et al. 2014). Receptor activation results in the release of various proinflammatory cytokines and chemokines, including TNF- $\alpha$ and interleukin $1 \beta$ (IL-1 $\beta$ ), leading to systemic pathology and many of the symptoms of malaria such as paroxysms of fever (see Milner 2016).

The long period required for acquisition of natural immunity to malaria and the lack of "sterile" immunity to this infection have led to the suggestion that dysregulation of the host immune system contributes to this incomplete immunity. In addition, reports that antibodies to some parasite antigens are short-lived has led to the suggestion that there are deficiencies in the generation and maintenance of memory B cells in malaria-infected individuals (Portugal et al. 2013; Scholzen and Sauerwein 2013). However, whether this is responsible for the slow development of naturally acquired immunity has been questioned (Hviid et al. 2015) It has also been observed that malaria-exposed individuals have a larger proportion of atypical memory B cells (Weiss et al. 2009), although their specificity is not known and this has not been directly linked with malaria infection. Additional investigations of different B-cell populations, immunologic memory, and protective immune mechanisms will be required to illuminate these issues.

\section{IMMUNE RESPONSES TO SEXUAL AND MOSQUITO-STAGE PARASITES}

\section{Characterization of Parasite Sexual Stages}

Although asexual stages are responsible for the clinical symptoms of malaria, its transmission requires differentiation to sexual stages, which can be picked up and transmitted by anopheline mosquitoes (Nilsson et al. 2015; Mitchell and Catteruccia 2016). Sexual stages II-IV are sequestered from the peripheral circulation, but eventually stage- $\mathrm{V}$ male and female gametocytes reemerge into the bloodstream where they can be engulfed by mosquitoes taking a blood meal. Markers of the various gametocyte 
stages, as well as proteins specific to male or female gametocytes, have been sought for some time. However, mature gametocytes no longer present var gene products on the red cell surface and other surface markers have not been definitively identified (Sutherland 2009). Once in the mosquito, the male and female gametocytes emerge from the red cells in the mosquito midgut as gametes where fertilization occurs. At this point, the gametes, zygotes, and ookinetes are accessible to antibodies, leukocytes, or other factors, such as complement, which may be present in the blood meal.

Initial evidence that vertebrate immune responses can interfere with sexual-stage development and mosquito infection led to the concept of transmission-blocking vaccines (reviewed in Stowers and Carter 2001; Sinden 2010). The first studies were conducted in avian models of malaria when birds were immunized with killed blood containing gametocytes, making them less infectious to mosquitoes than controls (Huff et al. 1958). Almost two decades later, it was shown that chickens immunized with inactivated Plasmodium gallinaceum gametocytes produced a transmission-blocking activity found in the serum (Carter and Chen 1976; Gwadz 1976). Interestingly, these serum effectors did not affect the gametocytes directly but rather acted on the parasites in the mosquito. Transmission-blocking immunity was also reported with rodent and nonhuman primate malaria parasites (Gwadz and Green 1978; Mendis and Targett 1979). Identification of monoclonal antibodies with transmission-blocking activity in mosquito-feeding experiments facilitated identification of parasite antigens that were the targets of transmission-blocking activity and also established the critical role of antibodies in blocking transmission (Kaushal et al. 1983; Rener et al. 1983). These studies also resulted in a method to evaluate antibodies to sexual stages, viz., the standard mosquito membrane feeding assay (SMFA). In this assay, cultured gametocytes are incubated with antibodies and the mixture fed to anopheline mosquitoes; 1 week later, the oocysts on the mosquito midgut are enumerated. Recent efforts to qualify the SMFA and to analyze data derived from this assay have increased its applicability to transmission-blocking studies (Churcher et al. 2012; Miura et al. 2013a).

Such antibodies with transmission-blocking activity were then used to identify the parasite antigens they targeted, primarily revealing molecules of $25,48 / 45$, and $230 \mathrm{kDa}$ (Rener et al. 1983). More recently, efforts have been made to exploit the sequencing of plasmodial genomes as well as transcriptional and proteomic analysis to identify sexual-stage proteins or mRNAs for such proteins found in these stages and the mosquito (Hall et al. 2005; Khan et al. 2005; Silvestrini et al. 2005; Young et al. 2005). These would be possible targets for antibodies or drugs targeting gametocytes.

\section{Identification and Investigations of Pre- and Postfertilization Proteins}

For convenience, immune responses to parasite antigens have been divided into prefertilization and postfertilization proteins (reviewed in Pradel 2007; Nikolaeva et al. 2015; Wu et al. 2015).

\section{Prefertilization Antigens}

Most studies have focused on a limited set of parasite proteins and considerable difficulties have been encountered in expressing many of them in recombinant platforms, particularly antigens such as Pfs 230 and Pfs48/45, which are members of the 6-cysteine protein family. These proteins are characterized by repeating motifs of six conserved cysteine residues, which are coexpressed in gametocytes and have been implicated in the process of fertilization of male and female gametes. Interestingly, activity of antibodies to Pfs 230 in the SMFA is enhanced by serum complement, which apparently retains some activity in the blood meal (Read et al. 1994). Although presenting difficulties in expression, inclusion of such proteins in a transmission-blocking vaccine has the potential for boosting by natural infection, which is not the case for proteins expressed only in the mosquito vector. In addition, although some polymorphism has been reported for these molecules, it is less than that of many asexual-stage antigens (Niederwieser et al. 2001). Similarly, evidence 
has been presented that the $P$. vivax protein (Pvs230) can also elicit transmission-blocking activity (Tachibana et al. 2012).

\section{Postfertilization Antigens}

Because proteins such as Pfs 25 and Pvs25 have limited or no expression in the vertebrate host, they are not subject to selection by the vertebrate immune system and consequently are generally quite conserved (Tsuboi et al. 1998). However, as noted, this limits the possibility of boosting of vaccine-induced immune responses by natural infection. The best studied of the postfertilization proteins is $\mathrm{Pfs} 25$ and to a lesser extent its homolog in P. vivax (Pvs25). Each is found on the surface of the ookinete and includes four epidermal growth factor (EGF)like domains. Structural studies have revealed Pvs25 to be a flat triangular molecule that could tile the surface of ookinetes; residues forming the triangle are conserved in P25 molecules from all plasmodial species (Saxena et al. 2006). The report of anti-Pfs 25 monoclonal antibodies and polyclonal antibodies, which have transmission-blocking activity in SMFA experiments have supported its candidacy as a potential transmission-blocking vaccine (Kaslow et al. 1988). Whether effector antibodies prevent ookinete crossing of the midgut or have other roles in reducing oocyst numbers is not yet clear. Further, estimates of specific antibody concentration required to attain 50\% inhibition of oocyst density in the SMFA indicate that relatively high antibody concentrations, approximately $100 \mu \mathrm{g} / \mathrm{ml}$, will be required (Cheru et al. 2010), and eliciting high, long-lasting antibody titers in humans remains a challenge.

Two recent studies have sought to compare immune responses to different transmissionblocking antigens using the SMFA (Miura et al. 2013c; Kapulu et al. 2015). In one study, proteins were produced in the wheat germ cellfree expression system and antibodies generated in mice. Detailed analysis of SMFA results showed that Pfs25 elicited IgGs with higher inhibition than anti-Pfs 230 or anti-HAP2. This was the first demonstration that $P$. falciparum HAP2, a protein also involved in fertilization, could elicit antibodies with transmissionblocking activity. In the second study (Kapulu et al. 2015), viral vectors encoding parasite proteins were used to immunize mice and the resultant antibodies compared; both anti-Pfs230$\mathrm{C}$ and anti-Pfs 25 gave very high levels of blockade in the SMFA.

Other postfertilization proteins, some of which have been investigated as potential transmission-blocking vaccine candidates, include micronemal proteins of the ookinete, proteins found in the cytoplasmic crystalloid organelle, as well as the enzymes such as enolase and chitinase produced by the parasite (reviewed by Pradel 2007; Nikolaeva et al. 2015; Wu et al. 2015). Many of these proteins are likely to have important roles in exodus from the blood meal, attachment to the midgut wall, invasion of the midgut, protection of the parasite, and oocyst development but have not been well studied in terms of immune responses.

\section{Host Immune Responses to Sexual- Stage Parasites}

Host immune responses to gametocyte surface membranes have been examined in some individuals from malaria-endemic areas to explore the hypothesis that such natural immune responses could either reduce gametocyte sequestration, gametocyte density in vivo, or infectivity to mosquitoes (Bousema and Drakeley 2011). However, it has proven difficult to show recognition of stage- $\mathrm{V}$-specific proteins on the surface of infected red cells. Some data have been presented that sera from African children recognize these cells by flow cytometry (Saeed et al. 2008); another study reported seroreactivity to gametocytes by IFA, which correlated with reduction of gametocyte density (Baird et al. 1991). Detailed investigation of the gametocyte surface at various stages of differentiation will be important future activities.

With regard to specific antigens present in gametes or zygotes, several studies have reported antibodies in those living in malaria-endemic areas to Pfs230 (Graves et al. 1988; Healer et al. 1999; Bousema et al. 2010; Miura et al. 2013c; Jones et al. 2015) and to Pfs48/45 (Roef- 
fen et al. 1996; Bousema et al. 2010; Jones et al. 2015). Some of these responses have been correlated with transmission-reducing activity as measured by SMFA in the same sera. Evidence for the presence of antibodies to Pfs25 in human populations is inconsistent, perhaps depending on the methodology used (Riley et al. 1994; Miura et al. 2013c).

In addition to the immune responses of the vertebrate host, it is clear that the mosquito vector has an innate immune system, which can also affect the outcome of infection by plasmodia. Those responses are beyond the scope of this review but are discussed in Crompton et al. (2014).

\section{FUTURE PERSPECTIVES}

Overall, studies on antiparasite immune responses of the vertebrate host have identified a repertoire of potential immune effector mechanisms and number of antigens as candidates for vaccine development. In the process these studies have also identified some of the many challenges that lie ahead.

The positive results obtained in the phase III trial of the RTS,S vaccine have established that a malaria vaccine is potentially feasible. Given these results, the next 5 years should see major efforts to develop a more advanced formulation, an effort that will require a more nuanced understanding of the interactions between the host and the infecting sporozoite. Characterizing the specificities and affinities of anti-CSP protective antibodies, identifying optimal immunization strategies, and addressing issues of allelic polymorphism in the CSP protein should contribute to improvements in the vaccine In addition, expanded efforts should be made to identify other important PE antigens and to develop methodologies that can elicit antigenspecific $\mathrm{CD}^{+} \mathrm{T}$ cells in humans.

As discussed previously, the adoptive transfer of antibodies from individuals living in endemic areas drastically reduced parasitemia in $P$. falciparum-infected children. The antiparasite phenotype of naturally acquired immunity is clearly attributable to the inhibitory effect of antibodies on the progressive development of asexual stages. To date, vaccine studies with asexual stages have focused mostly on single antigens with a likely functional role in parasite replication. Although this may be a sensible approach, there is no evidence that protective immunity is restricted to the recognition of only a few antigens. In fact, it is possible that vaccines inducing broad, multiantigen immune responses may be more effective and long lasting. Also, although the prospect is daunting, we need to pursue efforts to identify conserved targets on the surface of the infected red cell. It is therefore urgent to develop extensive programs to design vaccines consisting of multiple antigens from different parasite stages. This is a major challenge as multispecific immune responses may not be easy to induce, as it is not uncommon to find antigen competition/interference when using combination vaccines. Moreover, it is not clear that there exist sensitive methodologies that can show the occurrence of additive or synergistic effects of the induced immune responses.

The extensive antigenic diversity in antigens from PE and asexual stages, which are currently studied for vaccine development is a significant hurdle. However, this should not be considered an insurmountable obstacle, as new biotechnological advances should make possible the development of multiallelic vaccine constructs. Finally, recent evidence indicating that individuals exposed to parasite infection undergo immune exhaustion and a possible inability to develop an efficient immunological memory is a matter of concern. It is unclear the extent to which these immune dysfunctions may impair the development of immune responses induced by vaccines or if it may decrease vaccine efficacy.

Resurgent interest in the sexual stages of parasites and in malaria transmission in the field has generated interest in the possibility of a transmission-blocking component of a multistage vaccine. Whether the current antigens identified or other parasite or mosquito antigens can elicit sufficiently high titers of antibodies in humans to affect transmission to the mosquito will be an important question to answer in the next 5 years. Also, we must seek vaccine formulations and expression platforms 
that generate longer lasting humoral immune responses, because responses to some transmission reducing parasite proteins may not be boosted by natural infection. Finally, issues of what level of responses in a population are required to reduce transmission in a given area and how to determine that level must be approached. Nevertheless, a component of a vaccine that could aid in reducing transmission below a critical threshold would be an important contribution to malaria vaccine development.

\section{CONCLUDING REMARKS}

Characterization of immune responses induced by natural exposure to parasites has facilitated the identification of mechanisms of immunity that provide partial protection, particularly for immune responses to asexual stages. These studies show that naturally acquired immune responses against asexual stages are effective against parasites and that these responses reduce morbidity, even though they do not cause full parasite clearance. In contrast, naturally acquired immune responses against PE and sexual stages are of low magnitude and there is no clear evidence that they have a protective effect or mediate clinical immunity. The interest in immune responses to $\mathrm{PE}$ and sexual stages and the antigens they recognize derives from experimental vaccine studies in animal models or in human trials in the case of attenuated sporozoites, which showed the development of sterilizing immunity. The challenge now is to transform these findings into a highly effective vaccine for malaria.

Considerable advances have been made in reducing malaria in many parts of the world over the past decade using existing tools. However, the logistics and financing required to retain and to expand these advances in the face of antimalarial drug resistance and declining efficacy of insecticides will be challenging. As we consider moving beyond the current situation into an era of malaria eradication, the development and deployment of a highly effective malaria vaccine is still a critically important but unrealized component in the portfolio of responses to this global challenge. Pursuing a more complete and detailed view of the immunologic interface between host and the various parasite stages should enhance the opportunities for developing such a vaccine.

\section{ACKNOWLEDGMENTS}

We gratefully acknowledge all the scientists and study volunteers over many decades who have contributed to our knowledge of immune responses in malaria. Many of these publications could not be included because of space limitations, and in some cases we have used reviews of various topics. C.A.L. acknowledges support from the Intramural Research Program of the National Institute of Allergy and Infectious Diseases, National Institutes of Health (NIH). F.Z. is supported by $\mathrm{NIH} /$ National Institute of Allergy and Infectious Diseases (NIAID) Grant R01 AI44375. We also thank Ms. Daria Nikolaeva for assistance with the sexual-stage references.

\section{REFERENCES}

${ }^{*}$ Reference is also in this collection.

Anum D, Kusi KA, Ganeshan H, Hollingdale MR, Ofori MF, Koram KA, Gyan BA, Adu-Amankwah S, Badji E, Huang J, et al. 2015. Measuring naturally acquired ex vivo IFN- $\gamma$ responses to Plasmodium falciparum cell-traversal protein for ookinetes and sporozoites (CelTOS) in Ghanaian adults. Malaria J 14: 20.

Ataide R, Mayor A, Rogerson SJ. 2014. Malaria, primigravidae, and antibodies: Knowledge gained and future perspectives. Trends Parasitol 30: 85-94.

Baird JK, Jones TR, Purnomo, Masbar S, Ratiwayanto S, Leksana B. 1991. Evidence for specific suppression of gametocytemia by Plasmodium falciparum in residents of hyperendemic Irian Jaya. Am J Trop Med Hyg 44: $183-190$.

Beeson JG, Osier FH, Engwerda CR. 2008. Recent insights into humoral and cellular immune responses against malaria. Trends Parasitol 24: 578-584.

Bergmann-Leitner ES, Mease RM, De La Vega P, Savranskaya T, Polhemus M, Ockenhouse C, Angov E. 2010. Immunization with pre-erythrocytic antigen CelTOS from Plasmodium falciparum elicits cross-species protection against heterologous challenge with Plasmodium berghei. PLoS ONE 5: e12294.

Bongfen SE, Ntsama PM, Offner S, Smith T, Felger I, Tanner M, Alonso P, Nebie I, Romero JF, Silvie O, et al. 2009. The N-terminal domain of Plasmodium falciparum circumsporozoite protein represents a target of protective immunity. Vaccine 27: 328-335. 
Bouharoun-Tayoun H, Druilhe P. 1992. Plasmodium falciparum malaria: Evidence for an isotype imbalance which may be responsible for delayed acquisition of protective immunity. Infect Immun 60: 1473-1481.

Bousema T, Drakeley C. 2011. Epidemiology and infectivity of Plasmodium falciparum and Plasmodium vivax gametocytes in relation to malaria control and elimination. Clin Microbiol Rev 24: $377-410$

Bousema T, Roeffen W, Meijerink H, Mwerinde H, Mwakalinga S, van Gemert GJ, van de Vegte-Bolmer M, Mosha F Targett G, Riley EM, et al. 2010. The dynamics of naturally acquired immune responses to Plasmodium falciparum sexual stage antigens Pfs 230 and Pfs $48 / 45$ in a low endemic area in Tanzania. PLoS ONE 5: e14114.

Bull PC, Lowe BS, Kortok M, Molyneux CS, Newbold CI, Marsh K. 1998. Parasite antigens on the infected red cell surface are targets for naturally acquired immunity to malaria. Nat Med 4: 358-360.

Burns JM Jr, Majarian WR, Young JF, Daly TM, Long CA 1989. A protective monoclonal antibody recognizes an epitope in the carboxyl-terminal cysteine-rich domain in the precursor of the major merozoite surface antigen of the rodent malarial parasite, Plasmodium yoelii. J Immunol 143: 2670-2676.

Campbell GH, Collins FH, Brandling-Bennett AD, Schwartz IK, Roberts JM. 1987. Age-specific prevalence of antibody to a synthetic peptide of the circumsporozoite protein of Plasmodium falciparum in children from three villages in Kenya. Am J Trop Med Hyg 37: 220-224.

Carlson J, Helmby H, Hill AV, Brewster D, Greenwood BM, Wahlgren M. 1990. Human cerebral malaria: Association with erythrocyte rosetting and lack of anti-rosetting antibodies. Lancet 336: 1457-1460.

Carter R, Chen DH. 1976. Malaria transmission blocked by immunisation with gametes of the malaria parasite. $\mathrm{Na}$ ture 263: 57-60.

Chan JA, Howell KB, Reiling L, Ataide R, Mackintosh CL, Fowkes FJ, Petter M, Chesson JM, Langer C, Warimwe GM, et al. 2012. Targets of antibodies against Plasmodium falciparum-infected erythrocytes in malaria immunity. $J$ Clin Invest 122: $3227-3238$.

Chan JA, Fowkes FJ, Beeson JG. 2014. Surface antigens of Plasmodium falciparum-infected erythrocytes as immune targets and malaria vaccine candidates. Cell Mol Life Sci 71: 3633-3657.

Chen L, Lopaticki S, Riglar DT, Dekiwadia C, Uboldi AD, Tham WH, O'Neill MT, Richard D, Baum J, Ralph SA, et al. 2011. An EGF-like protein forms a complex with PfRh5 and is required for invasion of human erythrocytes by Plasmodium falciparum. PLoS Pathog 7: e1002199.

Cheru L, Wu Y, Diouf A, Moretz SE, Muratova OV, Song G, Fay MP, Miller LH, Long CA, Miura K. 2010. The IC $_{50}$ of anti-Pfs 25 antibody in membrane-feeding assay varies among species. Vaccine 28: 4423-4429.

Churcher TS, Blagborough AM, Delves M, Ramakrishnan C, Kapulu MC, Williams AR, Biswas S, Da DF, Cohuet A, Sinden RE. 2012. Measuring the blockade of malaria transmission-An analysis of the standard membrane feeding assay. Int J Parasitol 42: 1037-1044.

Cohen S, McGregor IA, Carrington S. 1961. $\gamma$-Globulin and acquired immunity to human malaria. Nature 192: 733 737.
Coppi A, Natarajan R, Pradel G, Bennett BL, James ER, Roggero MA, Corradin G, Persson C, Tewari R, Sinnis P. 2011. The malaria circumsporozoite protein has two functional domains, each with distinct roles as sporozoites journey from mosquito to mammalian host. J Exp Med 208: 341-356.

Crompton PD, Kayala MA, Traore B, Kayentao K, Ongoiba A, Weiss GE, Molina DM, Burk CR, Waisberg M, Jasinskas A, et al. 2010. A prospective analysis of the Ab response to Plasmodium falciparum before and after a malaria season by protein microarray. Proc Natl Acad Sci 107: 6958-6963.

Crompton PD, Moebius J, Portugal S, Waisberg M, Hart G, Garver LS, Miller LH, Barillas-Mury C, Pierce SK. 2014. Malaria immunity in man and mosquito: Insights into unsolved mysteries of a deadly infectious disease. Annu Rev Immunol 32: 157-187.

Crosnier C, Bustamante LY, Bartholdson SJ, Bei AK, Theron M, Uchikawa M, Mboup S, Ndir O, Kwiatkowski DP, Duraisingh MT, et al. 2011. Basigin is a receptor essential for erythrocyte invasion by Plasmodium falciparum. $\mathrm{Na}$ ture 480: 534-537.

Daly TM, Long CA. 1993. A recombinant 15-kilodalton carboxyl-terminal fragment of Plasmodium yoelii yoelii 17XL merozoite surface protein 1 induces a protective immune response in mice. Infect Immun 61: 2462-2467.

Deans JA, Alderson T, Thomas AW, Mitchell GH, Lennox ES, Cohen S. 1982. Rat monoclonal antibodies which inhibit the in vitro multiplication of Plasmodium knowlesi. Clin Exp Immunol 49: 297-309.

de Groot AS, Johnson AH, Maloy WL, Quakyi IA, Riley EM, Menon A, Banks SM, Berzofsky JA, Good MF. 1989. Human $\mathrm{T}$ cell recognition of polymorphic epitopes from malaria circumsporozoite protein. J Immunol 142: 4000-4005.

Dolo A, Modiano D, Doumbo O, Bosman A, Sidibe T, Keita MM, Naitza S, Robson KJ, Crisanti A. 1999. Thrombospondin related adhesive protein (TRAP), a potential malaria vaccine candidate. Parassitologia 41: 425-428.

Domarle O, Migot-Nabias F, Mvoukani JL, Lu CY, Nabias R, Mayombo J, Tiga H, Deloron P. 1999. Factors influencing resistance to reinfection with Plasmodium falciparum. Am J Trop Med Hyg 61: 926-931.

Doolan DL, Houghten RA, Good MF. 1991. Location of human cytotoxic $\mathrm{T}$ cell epitopes within a polymorphic domain of the Plasmodium falciparum circumsporozoite protein. Int Immunol 3: 511-516.

Doolan DL, Khamboonruang C, Beck HP, Houghten RA, Good MF. 1993. Cytotoxic T lymphocyte (CTL) low-responsiveness to the Plasmodium falciparum circumsporozoite protein in naturally-exposed endemic populations: Analysis of human CTL response to most known variants. Int Immunol 5: 37-46.

Doolan DL, Hedstrom RC, Rogers WO, Charoenvit Y, Rogers M, de la Vega P, Hoffman SL. 1996. Identification and characterization of the protective hepatocyte erythrocyte protein $17 \mathrm{kDa}$ gene of Plasmodium yoelii, homolog of Plasmodium falciparum exported protein 1.J Biol Chem 271: $17861-17868$.

Doolan DL, Mu Y, Unal B, Sundaresh S, Hirst S, Valdez C, Randall A, Molina D, Liang X, Freilich DA, et al. 2008. Profiling humoral immune responses to $P$. falciparum 
infection with protein microarrays. Proteomics 8: 46804694.

Douglas AD, Williams AR, Illingworth JJ, Kamuyu G, Biswas S, Goodman AL, Wyllie DH, Crosnier C, Miura K, Wright GJ, et al. 2011. The blood-stage malaria antigen PfRH5 is susceptible to vaccine-inducible cross-strain neutralizing antibody. Nat Commun 2: 601.

Douglas AD, Williams AR, Knuepfer E, Illingworth JJ, Furze JM, Crosnier C, Choudhary P, Bustamante LY, Zakutansky SE, Awuah DK, et al. 2014. Neutralization of Plasmodium falciparum merozoites by antibodies against PfRH5. J Immunol 192: 245-258.

Douglas AD, Baldeviano GC, Lucas CM, Lugo-Roman LA, Crosnier C, Bartholdson SJ, Diouf A, Miura K, Lambert LE, Ventocilla JA, et al. 2015. A PfRH5-based vaccine is efficacious against heterologous strain blood-stage Plasmodium falciparum infection in aotus monkeys. Cell Host Microbe 17: 130-139.

Druilhe P, Pradier O, Marc JP, Miltgen F, Mazier D, Parent G. 1986. Levels of antibodies to Plasmodium falciparum sporozoite surface antigens reflect malaria transmission rates and are persistent in the absence of reinfection. Infect Immun 53: 393-397.

Dutta S, Dlugosz LS, Drew DR, Ge X, Ababacar D, Rovira YI, Moch JK, Shi M, Long CA, Foley M, et al. 2013. Overcoming antigenic diversity by enhancing the immunogenicity of conserved epitopes on the malaria vaccine candidate apical membrane antigen-1. PLoS Pathog 9: e1003840.

Espinosa DA, Gutierrez GM, Rojas-Lopez M, Noe AR, Shi L, Tse SW, Sinnis P, Zavala F. 2015. Proteolytic cleavage of the Plasmodium falciparum circumsporozoite protein is a target of protective antibodies. J Infect Dis 212: 11111119.

Esposito F, Lombardi S, Modiano D, Zavala F, Reeme J, Lamizana L, Coluzzi M, Nussenzweig RS. 1988. Prevalence and levels of antibodies to the circumsporozoite protein of Plasmodium falciparum in an endemic area and their relationship to resistance against malaria infection. Trans R Soc Trop Med Hyg 82: 827-832.

Esposito F, Lombardi S, Modiano D, Habluetzel A, Del Nero L, Lamizana L, Pietra V, Rotigliano G, Corradin G, Ravot E, et al. 1992. In vitro immune recognition of synthetic peptides from the Plasmodium falciparum CS protein by individuals naturally exposed to different sporozoite challenge. Immunol Lett 33: 187-199.

Ewer KJ, O'Hara GA, Duncan CJ, Collins KA, Sheehy SH, Reyes-Sandoval A, Goodman AL, Edwards NJ, Elias SC, Halstead FD, et al. 2013. Protective CD8 ${ }^{+}$T-cell immunity to human malaria induced by chimpanzee adenovirus-MVA immunisation. Nat Commun 4: 2836.

Fidock DA, Gras-Masse H, Lepers JP, Brahimi K, Benmohamed L, Mellouk S, Guerin-Marchand C, Londono A Raharimalala L, Meis JF, et al. 1994. Plasmodium falciparum liver stage antigen- 1 is well conserved and contains potent B and T cell determinants. J Immunol 153: 190 204.

Flanagan KL, Mwangi T, Plebanski M, Odhiambo K, Ross A, Sheu E, Kortok M, Lowe B, Marsh K, Hill AV. 2003. Ex vivo interferon- $\gamma$ immune response to thrombospondinrelated adhesive protein in coastal Kenyans: Longevity and risk of Plasmodium falciparum infection. Am J Trop Med Hyg 68: 421-430.

Fowkes FJ, Richards JS, Simpson JA, Beeson JG. 2010. The relationship between anti-merozoite antibodies and incidence of Plasmodium falciparum malaria: A systematic review and meta-analysis. PLoS Med 7: e1000218.

* Fried M, Duffy PE. 2016. Malaria during pregnancy. Cold Spring Harb Perspect Med doi: 10.1101/cshperspect. a025551.

Gazzinelli RT, Kalantari P, Fitzgerald KA, Golenbock DT. 2014. Innate sensing of malaria parasites. Nat Rev Immunol 14: 744-757.

Goel S, Palmkvist M, Moll K, Joannin N, Lara P, Akhouri RR, Moradi N, Ojemalm K, Westman M, Angeletti D, et al. 2015. RIFINs are adhesins implicated in severe Plasmodium falciparum malaria. Nat Med 21: 314-317.

Good MF, Pombo D, Quakyi IA, Riley EM, Houghten RA, Menon A, Alling DW, Berzofsky JA, Miller LH. 1988 Human T-cell recognition of the circumsporozoite protein of Plasmodium falciparum: Immunodominant T-cell domains map to the polymorphic regions of the molecule. Proc Natl Acad Sci 85: 1199-1203.

Graves PM, Carter R, Burkot TR, Quakyi IA, Kumar N. 1988. Antibodies to Plasmodium falciparum gamete surface antigens in Papua New Guinea sera. Parasite Immunol 10: 209-218.

Gray JC, Corran PH, Mangia E, Gaunt MW, Li Q, Tetteh KK, Polley SD, Conway DJ, Holder AA, Bacarese-Hamilton T, et al. 2007. Profiling the antibody immune response against blood stage malaria vaccine candidates. Clin Chem 53: 1244-1253.

Guerin-Marchand C, Druilhe P, Galey B, Londono A, Patarapotikul J, Beaudoin RL, Dubeaux C, Tartar A, Mercereau-Puijalon O, Langsley G. 1987. A liver-stage-specific antigen of Plasmodium falciparum characterized by gene cloning. Nature 329: 164-167.

Gwadz RW. 1976. Successful immunization against the sexual stages of Plasmodium gallinaceum. Science 193: 1150 1151.

Gwadz RW, Green I. 1978. Malaria immunization in Rhesus monkeys. A vaccine effective against both the sexual and asexual stages of Plasmodium knowlesi. J Exp Med 148: 1311-1323.

Hall N, Karras M, Raine JD, Carlton JM, Kooij TW, Berriman M, Florens L, Janssen CS, Pain A, Christophides GK, et al. 2005. A comprehensive survey of the Plasmodium life cycle by genomic, transcriptomic, and proteomic analyses. Science 307: 82-86.

Healer J, McGuinness D, Carter R, Riley E. 1999. Transmission-blocking immunity to Plasmodium falciparum in malaria-immune individuals is associated with antibodies to the gamete surface protein Pfs230. Parasitology 119: 425-433.

* Healer J, Cowman AF, Kaslow DC, Birkett AJ. 2016. Vaccines to accelerate malaria elimination and eventual eradication. Cold Spring Harb Perspect Med doi: 10.1101/ cshperspect.a025627.

Herrington D, Davis J, Nardin E, Beier M, Cortese J, Eddy H, Losonsky G, Hollingdale M, Sztein M, Levine M, et al. 1991. Successful immunization of humans with irradiated malaria sporozoites: Humoral and cellular responses 
of the protected individuals. Am J Trop Med Hyg 45: 539547.

Hoffman SL, Wistar R Jr, Ballou WR, Hollingdale MR, Wirtz RA, Schneider I, Marwoto HA, Hockmeyer WT. 1986. Immunity to malaria and naturally acquired antibodies to the circumsporozoite protein of Plasmodium falciparum. N Engl J Med 315: 601-606.

Hollingdale MR, Nardin EH, Tharavanij S, Schwartz AL, Nussenzweig RS. 1984. Inhibition of entry of Plasmodium falciparum and $P$. vivax sporozoites into cultured cells; An in vitro assay of protective antibodies. J Immunol 132: 909-913.

Hollingdale MR, Hogh B, Petersen E, Wirtz RA, Bjorkmann A. 1989. Age-dependent occurrence of protective antiPlasmodium falciparum sporozoite antibodies in a holoendemic area of Liberia. Trans R Soc Trop Med Hyg 83: 322-324.

Huff CG, Marchbank DF, Shiroishi T. 1958. Changes in infectiousness of malarial gametocytes. II: Analysis of the possible causative factors. Exp Parasitol 7: 399-417.

Hviid L, Jensen AT. 2015. PfEMP1—A parasite protein family of key importance in Plasmodium falciparum malaria immunity and pathogenesis. Adv Parasitol 88: 51-84.

Hviid L, Barfod L, Fowkes FJ. 2015. Trying to remember: Immunological B cell memory to malaria. Trends Parasitol 31: 89-94.

John CC, Zickafoose JS, Sumba PO, King CL, Kazura JW. 2003. Antibodies to the Plasmodium falciparum antigens circumsporozoite protein, thrombospondin-related adhesive protein, and liver-stage antigen 1 vary by ages of subjects and by season in a highland area of Kenya. Infect Immun 71: 4320-4325.

John CC, Moormann AM, Pregibon DC, Sumba PO, McHugh MM, Narum DL, Lanar DE, Schluchter MD, Kazura JW. 2005. Correlation of high levels of antibodies to multiple pre-erythrocytic Plasmodium falciparum antigens and protection from infection. Am J Trop Med Hyg 73: $222-228$.

John CC, Tande AJ, Moormann AM, Sumba PO, Lanar DE, Min XM, Kazura JW. 2008. Antibodies to pre-erythrocytic Plasmodium falciparum antigens and risk of clinical malaria in Kenyan children. J Infect Dis 197: 519-526.

Jones S, Grignard L, Nebie I, Chilongola J, Dodoo D, Sauerwein R, Theisen M, Roeffen W, Singh SK, Singh RK, et al 2015. Naturally acquired antibody responses to recombinant $\mathrm{Pfs} 230$ and $\mathrm{Pfs} 48 / 45$ transmission blocking vaccine candidates. J Infect 71: 117-127.

Kapulu MC, Da DF, Miura K, Li Y, Blagborough AM, Churcher TS, Nikolaeva D, Williams AR, Goodman AL, Sangare I, et al. 2015. Comparative assessment of transmission-blocking vaccine candidates against Plasmodium falciparum. Sci Rep 5: 11193.

Kariu T, Ishino T, Yano K, Chinzei Y, Yuda M. 2006. CelTOS, a novel malarial protein that mediates transmission to mosquito and vertebrate hosts. Mol Microbiol 59: 13691379.

Kaslow DC, Quakyi IA, Syin C, Raum MG, Keister DB, Coligan JE, McCutchan TF, Miller LH. 1988. A vaccine candidate from the sexual stage of human malaria that contains EGF-like domains. Nature 333: 74-76.

Kaushal DC, Carter R, Rener J, Grotendorst CA, Miller LH, Howard RJ. 1983. Monoclonal antibodies against surface determinants on gametes of Plasmodium gallinaceum block transmission of malaria parasites to mosquitoes. $J$ Immunol 131: 2557-2562.

Khan SM, Franke-Fayard B, Mair GR, Lasonder E, Janse CJ, Mann M, Waters AP. 2005. Proteome analysis of separated male and female gametocytes reveals novel sex-specific Plasmodium biology. Cell 121: 675-687.

Kurtis JD, Hollingdale MR, Luty AJ, Lanar DE, Krzych U, Duffy PE. 2001. Pre-erythrocytic immunity to Plasmodium falciparum: The case for an LSA-1 vaccine. Trends Parasitol 17: 219-223.

Lamarque M, Besteiro S, Papoin J, Roques M, Vulliez-Le Normand B, Morlon-Guyot J, Dubremetz JF, Fauquenoy S, Tomavo S, Faber BW, et al. 2011. The RON2-AMA1 interaction is a critical step in moving junction-dependent invasion by apicomplexan parasites. PLoS Pathog 7: e1001276.

Langhorne J, Ndungu FM, Sponaas AM, Marsh K. 2008. Immunity to malaria: More questions than answers. Nat Immunol 9: 725-732.

Mackintosh CL, Mwangi T, Kinyanjui SM, Mosobo M, Pinches R, Williams TN, Newbold CI, Marsh K. 2008. Failure to respond to the surface of Plasmodium falciparum infected erythrocytes predicts susceptibility to clinical malaria amongst African children. Int J Parasitol 38: 1445-1454.

Majarian WR, Daly TM, Weidanz WP, Long CA. 1984. Passive immunization against murine malaria with an IgG3 monoclonal antibody. J Immunol 132: 3131-3137.

Marsh K, Kinyanjui S. 2006. Immune effector mechanisms in malaria. Parasite Immunol 28: 51-60.

Marsh K, Hayes RH, Carson DC, Otoo L, Shenton F, Byass P, Zavala F, Greenwood BM. 1988. Anti-sporozoite antibodies and immunity to malaria in a rural Gambian population. Trans R Soc Trop Med Hyg 82: 532-537.

Mellouk S, Mazier D, Druilhe P, Berbiguier N, Danis M. 1986. In vitro and in vivo results suggesting that antisporozoite antibodies do not totally block Plasmodium falciparum sporozoite infectivity. N Engl J Med 315: 648.

Mendis KN, Targett GA. 1979. Immunisation against gametes and asexual erythrocytic stages of a rodent malaria parasite. Nature 277: 389-391.

* Milner DA. 2016. Malaria pathogenesis. Cold Spring Harb Perspect Med doi: 10.1101/cshperspect.a025569.

* Mitchell SN, Catteruccia F. 2016. Anopheline reproductive biology: Impacts on vectorial capacity and potential avenues for malaria control. Cold Spring Harb Perspect Med doi: 10.1101/cshperspect.a025593.

Miura K, Deng B, Tullo G, Diouf A, Moretz SE, Locke E, Morin M, Fay MP, Long CA. 2013a. Qualification of standard membrane-feeding assay with Plasmodium falciparum malaria and potential improvements for future assays. PLoS ONE 8: e57909.

Miura K, Herrera R, Diouf A, Zhou H, Mu J, Hu Z, MacDonald NJ, Reiter K, Nguyen V, Shimp RL Jr, et al. 2013b. Overcoming allelic specificity by immunization with five allelic forms of Plasmodium falciparum apical membrane antigen 1. Infect Immun 81: 1491-1501.

Miura K, Takashima E, Deng B, Tullo G, Diouf A, Moretz SE, Nikolaeva D, Diakite M, Fairhurst RM, Fay MP, et al. 2013c. Functional comparison of Plasmodium falciparum 
transmission-blocking vaccine candidates by the standard membrane-feeding assay. Infect Immun 81: 4377 4382.

Nardin EH, Nussenzweig RS, McGregor IA, Bryan JH. 1979. Antibodies to sporozoites: Their frequent occurrence in individuals living in an area of hyperendemic malaria. Science 206: 597-599.

Niang M, Bei AK, Madnani KG, Pelly S, Dankwa S, Kanjee U, Gunalan K, Amaladoss A, Yeo KP, Bob NS, et al. 2014. STEVOR is a Plasmodium falciparum erythrocyte binding protein that mediates merozoite invasion and rosetting. Cell Host Microbe 16: 81-93.

Niederwieser I, Felger I, Beck HP. 2001. Limited polymorphism in Plasmodium falciparum sexual-stage antigens. Am J Trop Med Hyg 64: 9-11.

Nikolaeva D, Draper SJ, Biswas S. 2015. Toward the development of effective transmission-blocking vaccines for malaria. Expert Rev Vaccines 14: 653-680.

Nilsson SK, Childs LM, Buckee C, Marti M. 2015. Targeting human transmission biology for malaria elimination. PLoS Pathog 11: e1004871.

Nussenzweig V, Nussenzweig RS. 1989. Rationale for the development of an engineered sporozoite malaria vaccine. Adv Immunol 45: 283-334.

Nussenzweig RS, Vanderberg J, Most H, Orton C. 1967. Protective immunity produced by the injection of $\mathrm{x}$-irradiated sporozoites of Plasmodium berghei. Nature 216: $160-162$.

Ogutu BR, Apollo OJ, McKinney D, Okoth W, Siangla J, Dubovsky F, Tucker K, Waitumbi JN, Diggs C, Wittes J, et al. 2009. Blood stage malaria vaccine eliciting high antigen-specific antibody concentrations confers no protection to young children in Western Kenya. PLoS ONE 4: e4708.

Ong'echa JM, Lal AA, Terlouw DJ, Ter Kuile FO, Kariuki SK, Udhayakumar V, Orago AS, Hightower AW, Nahlen BL, Shi YP. 2003. Association of interferon- $\gamma$ responses to pre-erythrocytic stage vaccine candidate antigens of Plasmodium falciparum in young Kenyan children with improved hemoglobin levels. XV: Asembo Bay Cohort Project. Am J Trop Med Hyg 68: 590-597.

Osier FH, Fegan G, Polley SD, Murungi L, Verra F, Tetteh KK, Lowe B, Mwangi T, Bull PC, Thomas AW, et al. 2008. Breadth and magnitude of antibody responses to multiple Plasmodium falciparum merozoite antigens are associated with protection from clinical malaria. Infect Immun 76: 2240-2248.

Persson C, Oliveira GA, Sultan AA, Bhanot P, Nussenzweig V, Nardin E. 2002. Cutting edge: A new tool to evaluate human pre-erythrocytic malaria vaccines: Rodent parasites bearing a hybrid Plasmodium falciparum circumsporozoite protein. J Immunol 169: 6681-6685.

Portugal S, Pierce SK, Crompton PD. 2013. Young lives lost as B cells falter: What we are learning about antibody responses in malaria. J Immunol 190: 3039-3046.

Pradel G. 2007. Proteins of the malaria parasite sexual stages: Expression, function and potential for transmission blocking strategies. Parasitology 134: 1911-1929.

Read D, Lensen AH, Begarnie S, Haley S, Raza A, Carter R. 1994. Transmission-blocking antibodies against multiple, non-variant target epitopes of the Plasmodium fal- ciparum gamete surface antigen Pfs 230 are all complement-fixing. Parasite Immunol 16: 511-519.

Reddy KS, Amlabu E, Pandey AK, Mitra P, Chauhan VS, Gaur D. 2015. Multiprotein complex between the GPIanchored CyRPA with PfRH5 and PfRipr is crucial for Plasmodium falciparum erythrocyte invasion. Proc Natl Acad Sci 112: 1179-1184.

Remarque EJ, Faber BW, Kocken CH, Thomas AW. 2008. Apical membrane antigen 1: A malaria vaccine candidate in review. Trends Parasitol 24: 74-84.

Rener J, Graves PM, Carter R, Williams JL, Burkot TR. 1983. Target antigens of transmission-blocking immunity on gametes of Plasmodium falciparum. J Exp Med 158: $976-$ 981.

Rieckmann KH, Beaudoin RL, Cassells JS, Sell KW. 1979. Use of attenuated sporozoites in the immunization of human volunteers against falciparum malaria. Bull World Health Organ 57: 261-265.

Riley EM, Allen SJ, Bennett S, Thomas PJ, O'Donnell A, Lindsay SW, Good MF, Greenwood BM. 1990. Recognition of dominant $\mathrm{T}$ cell-stimulating epitopes from the circumsporozoite protein of Plasmodium falciparum and relationship to malaria morbidity in Gambian children. Trans R Soc Trop Med Hyg 84: 648-657.

Riley EM, Bennett S, Jepson A, Hassan-King M, Whittle H, Olerup O, Carter R. 1994. Human antibody responses to Pfs 230, a sexual stage-specific surface antigen of Plasmodium falciparum: Non-responsiveness is a stable phenotype but does not appear to be genetically regulated. Parasite Immunol 16: 55-62.

Robson KJ, Hall JR, Jennings MW, Harris TJ, Marsh K, Newbold CI, Tate VE, Weatherall DJ. 1988. A highly conserved amino-acid sequence in thrombospondin, properdin and in proteins from sporozoites and blood stages of a human malaria parasite. Nature 335: 79-82.

Roeffen W, Mulder B, Teelen K, Bolmer M, Eling W, Targett GA, Beckers PJ, Sauerwein R. 1996. Association between anti-Pfs $48 / 45$ reactivity and $P$. falciparum transmissionblocking activity in sera from Cameroon. Parasite Immunol 18: 103-109.

Rogers WO, Malik A, Mellouk S, Nakamura K, Rogers MD, Szarfman A, Gordon DM, Nussler AK, Aikawa M, Hoffman SL. 1992. Characterization of Plasmodium falciparum sporozoite surface protein 2. Proc Natl Acad Sci 89: 9176-9180.

Sabchareon A, Burnouf T, Ouattara D, Attanath P, Bouharoun-Tayoun H, Chantavanich P, Foucault C, Chongsuphajaisiddhi T, Druilhe P. 1991. Parasitologic and clinical human response to immunoglobulin administration in falciparum malaria. Am J Trop Med Hyg 45: 297-308.

Saeed M, Roeffen W, Alexander N, Drakeley CJ, Targett GA, Sutherland CJ. 2008. Plasmodium falciparum antigens on the surface of the gametocyte-infected erythrocyte. PLoS ONE 3: e2280.

Sagara I, Dicko A, Ellis RD, Fay MP, Diawara SI, Assadou MH, Sissoko MS, Kone M, Diallo AI, Saye R, et al. 2009. A randomized controlled phase 2 trial of the blood stage AMA1-C1/Alhydrogel malaria vaccine in children in Mali. Vaccine 27: 3090-3098.

Saxena AK, Singh K, Su HP, Klein MM, Stowers AW, Saul AJ, Long CA, Garboczi DN. 2006. The essential mosquito- 
stage P25 and P28 proteins from Plasmodium form tilelike triangular prisms. Nat Struct Mol Biol 13: 90-91.

Scarselli E, Tolle R, Koita O, Diallo M, Muller HM, Fruh K, Doumbo O, Crisanti A, Bujard H. 1993. Analysis of the human antibody response to thrombospondin-related anonymous protein of Plasmodium falciparum. Infect Immun 61: 3490-3495.

Scholzen A, Sauerwein RW. 2013. How malaria modulates memory: Activation and dysregulation of B cells in Plasmodium infection. Trends Parasitol 29: 252-262.

Seder RA, Chang LJ, Enama ME, Zephir KL, Sarwar UN, Gordon IJ, Holman LA, James ER, Billingsley PF, Gunasekera A, et al. 2013. Protection against malaria by intravenous immunization with a nonreplicating sporozoite vaccine. Science 341: 1359-1365.

Silvestrini F, Bozdech Z, Lanfrancotti A, Di Giulio E, Bultrini E, Picci L, Derisi JL, Pizzi E, Alano P. 2005. Genome-wide identification of genes upregulated at the onset of gametocytogenesis in Plasmodium falciparum. Mol Biochem Parasitol 143: 100-110.

Sinden RE. 2010. A biologist's perspective on malaria vaccine development. Hum Vaccin 6: 3-11.

Smith JD. 2014. The role of PfEMP1 adhesion domain classification in Plasmodium falciparum pathogenesis research. Mol Biochem Parasitol 195: 82-87.

Srinivasan P, Ekanem E, Diouf A, Tonkin ML, Miura K, Boulanger MJ, Long CA, Narum DL, Miller LH. 2014. Immunization with a functional protein complex required for erythrocyte invasion protects against lethal malaria. Proc Natl Acad Sci 111: 10311-10316.

Stewart MJ, Nawrot RJ, Schulman S, Vanderberg JP. 1986. Plasmodium berghei sporozoite invasion is blocked in vitro by sporozoite-immobilizing antibodies. Infect Immun 51: 859-864.

Stowers A, Carter R. 2001. Current developments in malaria transmission-blocking vaccines. Expert Opin Biol Ther 1: 619-628.

Stowers AW, Cioce V, Shimp RL, Lawson M, Hui G, Muratova O, Kaslow DC, Robinson R, Long CA, Miller LH 2001. Efficacy of two alternate vaccines based on Plasmodium falciparum merozoite surface protein 1 in an Aotus challenge trial. Infect Immun 69: 1536-1546.

Stowers AW, Kennedy MC, Keegan BP, Saul A, Long CA, Miller LH. 2002. Vaccination of monkeys with recombinant Plasmodium falciparum apical membrane antigen 1 confers protection against blood-stage malaria. Infect Immun 70: 6961-6967.

Sutherland CJ. 2009. Surface antigens of Plasmodium falciparum gametocytes-A new class of transmission-blocking vaccine targets? Mol Biochem Parasitol 166: 93-98.

Tachibana M, Sato C, Otsuki H, Sattabongkot J, Kaneko O, Torii M, Tsuboi T. 2012. Plasmodium vivax gametocyte protein Pvs230 is a transmission-blocking vaccine candidate. Vaccine 30: 1807-1812.

Tapchaisri P, Chomcharn Y, Poonthong C, Asavanich A, Limsuwan S, Maleevan O, Tharavanij S, Harinasuta T. 1983. Anti-sporozoite antibodies induced by natural infection. Am J Trop Med Hyg 32: 1203-1208.

Terheggen U, Drew DR, Hodder AN, Cross NJ, Mugyenyi CK, Barry AE, Anders RF, Dutta S, Osier FH, Elliott SR, et al. 2014. Limited antigenic diversity of Plasmodium fal- ciparum apical membrane antigen 1 supports the development of effective multi-allele vaccines. BMC Med 12: 183.

Tham WH, Healer J, Cowman AF. 2012. Erythrocyte and reticulocyte binding-like proteins of Plasmodium falciparum. Trends Parasitol 28: 23-30.

Thera MA, Doumbo OK, Coulibaly D, Laurens MB, Ouattara A, Kone AK, Guindo AB, Traore K, Traore I, Kouriba B, et al. 2011. A field trial to assess a blood-stage malaria vaccine. N Engl J Med 365: 1004-1013.

Thomas AW, Waters AP, Carr D. 1990. Analysis of variation in PF83, an erythrocytic merozoite vaccine candidate antigen of Plasmodium falciparum. Mol Biochem Parasitol 42: $285-287$.

Tran TM, Ongoiba A, Coursen J, Crosnier C, Diouf A, Huang CY, Li S, Doumbo S, Doumtabe D, Kone Y, et al. 2014. Naturally acquired antibodies specific for Plasmodium falciparum reticulocyte-binding protein homologue 5 inhibit parasite growth and predict protection from malaria. J Infect Dis 209: 789-798.

Tsuboi T, Kaslow DC, Gozar MM, Tachibana M, Cao YM, Torii M. 1998. Sequence polymorphism in two novel Plasmodium vivax ookinete surface proteins, Pvs25 and Pvs28, that are malaria transmission-blocking vaccine candidates. Mol Med 4: 772-782.

Tsuji M, Zavala F. 2003. T cells as mediators of protective immunity against liver stages of Plasmodium. Trends Parasitol 19: 88-93.

Weiss GE, Crompton PD, Li S, Walsh LA, Moir S, Traore B, Kayentao K, Ongoiba A, Doumbo OK, Pierce SK. 2009. Atypical memory B cells are greatly expanded in individuals living in a malaria-endemic area. J Immunol 183: 2176-2182.

Wright GJ, Rayner JC. 2014. Plasmodium falciparum erythrocyte invasion: Combining function with immune evasion. PLoS Pathog 10: e1003943.

Wu Y, Sinden RE, Churcher TS, Tsuboi T, Yusibov V. 2015. Development of malaria transmission-blocking vaccines: From concept to product. Adv Parasitol 89: 109-152.

Young JA, Fivelman QL, Blair PL, de la Vega P, Le Roch KG, Zhou Y, Carucci DJ, Baker DA, Winzeler EA. 2005. The Plasmodium falciparum sexual development transcriptome: A microarray analysis using ontology-based pattern identification. Mol Biochem Parasitol 143: 67-79.

Zavala F, Masuda A, Graves PM, Nussenzweig V, Nussenzweig RS. 1985a. Ubiquity of the repetitive epitope of the CS protein in different isolates of human malaria parasites. J Immunol 135: 2790-2793.

Zavala F, Tam JP, Hollingdale MR, Cochrane AH, Quakyi I, Nussenzweig RS, Nussenzweig V. 1985b. Rationale for development of a synthetic vaccine against Plasmodium falciparum malaria. Science 228: 1436-1440.

Zevering Y, Khamboonruang C, Rungruengthanakit K, Tungviboonchai L, Ruengpipattanapan J, Bathurst I, Barr P, Good MF. 1994. Life-spans of human T-cell responses to determinants from the circumsporozoite proteins of Plasmodium falciparum and Plasmodium vivax. Proc Natl Acad Sci 91: 6118-6122.

Zhu J, Hollingdale MR. 1991. Structure of Plasmodium falciparum liver stage antigen-1. Mol Biochem Parasitol 48: 223-226. 


\section{$\&_{\mathrm{CSH}}^{\infty} \&$ Cold Spring Harbor

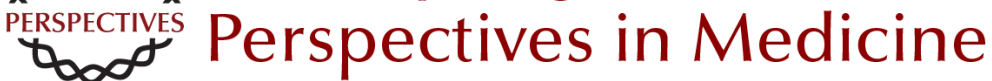

\section{Immune Responses in Malaria}

Carole A. Long and Fidel Zavala

Cold Spring Harb Perspect Med 2017; doi: 10.1101/cshperspect.a025577 originally published online April 7, 2017

\section{Subject Collection Malaria: Biology in the Era of Eradication}

Modern Vector Control

Neil F. Lobo, Nicole L. Achee, John Greico, et al.

Anopheline Reproductive Biology: Impacts on Vectorial Capacity and Potential Avenues for

Malaria Control Sara N. Mitchell and Flaminia Catteruccia

Current and Future Prospects for Preventing Malaria Transmission via the Use of Insecticides Hilary Ranson

\section{Molecular Signaling Involved in Entry and Exit of} Malaria Parasites from Host Erythrocytes Shailja Singh and Chetan E. Chitnis

Vaccines to Accelerate Malaria Elimination and Eventual Eradication Julie Healer, Alan F. Cowman, David C. Kaslow, et al.

Immune Responses in Malaria Carole A. Long and Fidel Zavala

Antimalarial Drug Resistance: A Threat to Malaria Elimination Didier Menard and Arjen Dondorp

Malaria during Pregnancy Michal Fried and Patrick E. Duffy

\section{Malaria Pathogenesis} Danny A. Milner, Jr.

Determinants of Malaria Transmission at the Population Level Teun Bousema and Chris Drakeley

\section{Host Cell Tropism and Adaptation of Blood-Stage Malaria Parasites: Challenges for Malaria Elimination Caeul Lim, Selasi Dankwa, Aditya S. Paul, et al.}

Malaria Transmission and Prospects for Malaria Eradication: The Role of the Environment Marcia C. Castro

The Biology of Plasmodium vivax John H. Adams and Ivo Mueller

\section{Malaria Genomics in the Era of Eradication Daniel E. Neafsey and Sarah K. Volkman \\ Malaria Epigenetics Alfred Cortés and Kirk W. Deitsch}

Malaria Parasite Liver Infection and
Exoerythrocytic Biology
Ashley M. Vaughan and Stefan H.I. Kappe

For additional articles in this collection, see http://perspectivesinmedicine.cshlp.org/cgi/collection/ 